\title{
The status of the northeastern Atlantic and Mediterranean small mussel drills of the Ocinebrina aciculata complex (Mollusca: Gastropoda: Muricidae), with the description of a new species
}

\author{
FABIO CROCETTA $^{1}$, GIUSEPPE BONOMOLO ${ }^{2}$, PAOLO GIULIO ALBANO $^{3}$, \\ ANDREA BARCO $^{4}$, ROLAND HOUART ${ }^{5}$ and MARCO OLIVERIO ${ }^{4}$ \\ ${ }^{1}$ Stazione Zoologica Anton Dohrn, Viale Antonio Dohrn, I-80121 Napoli, Italy. E-mail: fabio.crocetta@szn.it \\ 2 Via delle Terme 12, I-60035 Jesi, Italy. \\ ${ }^{3}$ Dipartimento di Biologia Evoluzionistica Sperimentale, Università di Bologna, Via Selmi 3, I-40126 Bologna, Italy. \\ ${ }^{4}$ Dipartimento di Biologia e Biotecnologie "Charles Darwin”, La Sapienza University, Viale dell’Università 32, \\ I-00185 Roma, Italy. \\ ${ }^{5}$ Institut royal des Sciences naturelles de Belgique, Rue Vautier 29, B-1000 Bruxelles, Belgium.
}

\begin{abstract}
SUMMARY: The northeastern Atlantic and Mediterranean small mussel drills of the Ocinebrina aciculata complex are here revised and consist of at least 3 species. The type species, Ocinebrina aciculata (Lamarck, 1822), characterized by a slender shell with rounded whorls and primary and secondary spiral cords of approximately similar size, lives throughout the northeastern Atlantic and Mediterranean Sea at depths usually ranging between 0 and $105 \mathrm{~m}$. Its synonymy is here stabilized by a neotype selection for Murex corallinus Scacchi, 1836. Ocinebrina corallinoides Pallary, 1912 (=Ocinebrina buzzurroi Cecalupo and Mariani, 2008, new synonymy), characterized by a strongly elongate and weakly convex shell and primary and secondary spiral cords of approximately similar size, is endemic to the Gulf of Gabès and is here considered a distinct species, pending genetic studies. Ocinebrina reinai $\mathrm{n}$. sp. is here described from the central Mediterranean Sea (where it is sympatric with O. aciculata) on the basis of morphological diagnostic features of shell (rarest presence of labral tooth, commoner presence of infrasutural apertural denticle, dark spots on the ribs and spiral sculpture with differently sized primary and secondary cords and smaller threads) and radula, confirmed by genetic data. Divergence in COI sequences with sympatric samples of $O$. aciculata $(>7 \%)$, confirm their status as a distinct species. A comparative table reporting diagnostic features of the congeneric species of the complex and those with which the new species was previously misidentified is offered.
\end{abstract}

Keywords: Mollusca, Muricidae, Ocinebrina aciculata complex, Ocinebrina reinai, new species, Mediterranean Sea.

RESUMEN: El estatus de las especies del grupo de OCINEbrina aCiculata (Mollusca: Gastropoda: Muricidae) Del AtLÁNTICO NORESTE y del MediterRáneO, CON LA DESCRIPCION DE UNA NUEVA ESPECIE. - Se revisa la taxonomía de las pequeñas especies de gasterópodos murícidos del grupo de Ocinebrina aciculata (Lamarck, 1822). Se consideran válidas tres especies, de las que una se describe como nueva. $O$. aciculata es la especie tipo del género, está caracterizada por una concha alargada, espiras redondeadas, cordones primarios y secundarios aproximadamente del mismo tamaño, y está distribuida en el área del Atlántico noreste y del Mediterráneo, entre 0 y $105 \mathrm{~m}$ de profundidad. Para estabilizar su sinonimia se ha seleccionado un neotipo para Murex corallinus Scacchi, 1836. O. corallinoides Pallary, 1912 (=Ocinebrina buzzurroi Cecalupo and Mariani, 2008, nueva sinonimia) es endémica del Golfo de Gabès, y se distingue por su concha muy alargada y poco convexa, con cordones primarios y secundarios aproximadamente del mismo tamaño. Se considera una especie distinta, a la espera de estudios genéticos. O. reinai $\mathrm{n}$. sp. se describe aqui, y se ha encontrado en Mediterráneo central, donde vive simpátrica con $O$. aciculata, de la que se distingue por caracteres morfológicos de la concha (rara presencia del diente labral, diente apertural infrasutural más frecuente, manchas oscuras en las costas axiales, cordones primarios y secundarios de tamaño diferente) y de la rádula, confirmados por datos genéticos. Las secuencias del gen mitocondrial COI indican una distancia genética con $O$. aciculata en simpatría de más de 7\%, confirmando su estatus de especie distinta. Se presenta una tabla comparativa de las diferencias entre las especies más similares.

Palabras clave: Mollusca, Muricidae, Ocinebrina aciculata complex, Ocinebrina reinai, nueva especie, mar Mediterráneo. 


\section{INTRODUCTION}

Molluscs are an important component of the marine fauna, and some groups, such as gastropods, play key roles in the benthic communities. Among them, muricids include predators of interest because of their potential impact on marine resources (oyster drills, mussel drills and rock shells). The taxonomy of the northeastern Atlantic and Mediterranean Muricidae has been recently reviewed (Houart 2001), highlighting the relative richness of this family in the area (ca. 60 species, of which around 40 in the Mediterranean), and the need for a careful revision of several groups. One of the genera still deserving special attention is Ocinebrina Jousseaume, 1880, comprising small species characterized by a fusiform shell up to 26.82 $\mathrm{mm}$ high, with a small paucispiral protoconch, 5-6.5 teleoconch whorls in the adults, a short and ventrally sealed siphonal canal and a varicose outer lip, with usually 5-6 internal denticles (Houart 2001). Their anatomy is largely unknown, with the sole exception of some recently figured radulae (e.g. Houart 2001, Cecalupo et al. 2008). Thirteen recent species of Ocinebrina are currently listed in the Mediterranean Sea (Houart 2001, Bonomolo and Buzzurro 2006, Cecalupo et al. 2008), split into 2 groups of morphological affinity:

- the Ocinebrina aciculata complex, including $O$. aciculata (Lamarck, 1822), the type species of the genus; $O$. buzzurroi Cecalupo and Mariani, 2008; and $O$. corallinoides Pallary, 1912;

- the Ocinebrina edwardsii complex, including $O$. edwardsii (Payraudeau, 1826); O. carmelae Cecalupo, Buzzurro and Mariani, 2008; O. erronea (Settepassi, 1977 ex Monterosato ms.); O. helleri (Brusina, 1865); O. hispidula Pallary, 1904; O. hybrida (Aradas and Benoît, 1876); O. ingloria (Crosse, 1865); O. nicolai Monterosato, 1884; O. paddeui Bonomolo and Buzzurro, 2006; and O. piantonii Cecalupo, Buzzurro and Mariani, 2008.

In the present paper we revise the Ocinebrina aciculata complex morphologically. Specimens ascribed to this complex are known throughout the Mediterranean Sea and the adjacent Atlantic waters up to Scilly and the Channel Islands to the north and Mauritania and northern Senegal to the south, at depths ranging between 0 and $105 \mathrm{~m}$. $O$. aciculata and $O$. corallinoides share slender shells with rounded whorls, a spiral sculpture of primary and secondary cords of approximately similar size and the presence of an occasional labral tooth. The synonymy of the former is here stabilized by the selection of a neotype for Murex corallinus Scacchi, 1836, while $O$. buzzurroi is considered as a junior synonym of the latter. Finally, a new species from the central Mediterranean is described on the basis of diagnostic morphological features of shell and soft parts, supported by genetic data on samples strictly sympatric with $O$. aciculata.

\section{MATERIALS AND METHODS}

Sample localities are summarized under each taxon in the Systematics, with detailed listing in Appendix B. Samples used for molecular taxonomy were collected by SCUBA diving in the "Secche di Tor Paterno" Marine Protected Area (Central Tyrrhenian Sea, Italy). Sampling methods include an air-lift suction sampler on coralligenous substrate and in rhizomes of Posidonia oceanica (Linnaeus) Delile, 1813, and a hand net with a $20 \times 40 \mathrm{~cm}$ opening on Posidonia leaves (P. G. Albano, L. Argenti, R. Maltini, M. Oliverio leg.).

Radulae were extracted from the buccal mass after tissues had been partly dissolved in a $10 \%$ solution of sodium hydroxide $(\mathrm{NaOH})$, then rinsed in distilled water, air dried, mounted on SEM stubs with opercula and protoconchs and gold-palladium coated in an SC7640 Sputter coater for SEM examination with a Jeol JSM$6700 \mathrm{~F}$ microscope.

Total genomic DNA was extracted using a standard proteinase $\mathrm{K}$ phenol-chloroform method with ethanol precipitation, as reported in Oliverio and Mariottini (2001). The DNA barcode fragments of the mitochondrial cytochrome oxidase I (COI) was amplified by polymerase chain reaction (PCR) using the universal primers LCO1490 and HCO2198 (Folmer et al. 1994). PCR conditions were 30 amplification cycles [30 s at $94^{\circ} \mathrm{C}, 30 \mathrm{~s}$ at $60^{\circ} \mathrm{C}, 1 \mathrm{~min}$ and $30 \mathrm{~s}$ at $\left.72^{\circ} \mathrm{C}\right]$. PCR products were purified using Exosap-IT (USB Corporation) and sequenced by Macrogen Inc. (Seoul, S. Korea). Sequences were readily aligned by hand. Base composition of nucleotide sequences was analysed with MEGA 5.0 (Tamura et al. 2007, 2011). Nucleotide homogeneity was tested with the $\chi^{2}$ statistics implemented in PAUP* (v. 4.0b10: Swofford 2002). Genetic variation (nucleotide diversity, haplotype diversity and nucleotide differences) was calculated using DnaSP 5.10 (Librado and Rozas 2009).

Phylogenetic relationships among the sequences were inferred by the neighbour-joining method, using the Kimura-2-Parameters (K2P) nucleotide substitution model, as implemented in the MEGA 5.0 software (Tamura et al. 2007, 2011). Relationships between individual sequences were also inferred on networks of haplotypes by statistical parsimony (by TCS v. June 2008: Jobb 2008).

\section{Abbreviations}

Abbreviations used for spiral cords and internal denticles in Muricidae follow Merle $(2001,2005)$ and are illustrated in Figure 2C: (IP) infrasutural primary cord, (adis) adapical infrasutural secondary cord, (abis) abapical infrasutural secondary cord, (P1-P6) primary cords of the convex part of the teleoconch whorl, (s1s6) secondary cords of the convex part of the teleoconch whorl, (t) threads, (ID) infrasutural apertural denticle on ventral face, and (D1-D5) apertural denticles of the convex part of the whorl on ventral face. 
Other abbreviations: CAS, Chicago Academy of Science (Chicago, Illinois); MHNG, Muséum d'Histoire Naturelle de Genève (Genève, Switzerland); MNHM, Museo Civico di Storia Naturale (Milano, Italy); MNHN, Muséum national d'Histoire naturelle (Paris, France); MSNT, Museo di Storia Naturale (Trieste, Italy); MSNVE, Museo di Storia Naturale (Venezia, Italy); MZN, Museo Zoologico, Centro Museale Università degli Studi di Napoli Federico II (Naples, Italy); NHMUK, The Natural History Museum (London, U.K.); SZN, Stazione Zoologica Anton Dohrn di Napoli (Naples, Italy); PAP, Paolo Giulio Albano private collection (Bologna, Italy); GBP, Giuseppe Bonomolo private collection (Jesi, Italy); FCP, Fabio Crocetta private collection (Naples, Italy); FDP, Fabio Daga private collection (Carbonia, Italy); SDP, Sergio Duraccio private collection (Naples, Italy); WHP, Winfried Engl private collection (Düsseldorf, Germany); GFP, Giuseppe Fasulo private collection (Naples, Italy); RHP, Roland Houart private collection (Landen, Belgium); MOP, Marco Oliverio private collection (Rome, Italy); MRP, Michele Reina private collection (Palermo, Italy); PSP, Paolo Sordino private collection (Naples, Italy); TH, total height; TW, total width; dd, empty shell(s); lv, live collected specimen(s).

\section{SYSTEMATICS}

Family Muricidae Rafinesque, 1815

Subfamily Ocenebrinae Cossman, 1903

Genus Ocinebrina Jousseaume, 1880

Type species by original designation: Fusus coralinus [sic!] Scacchi (= Murex corallinus Scacchi, $1836=$ Murex aciculatus Lamarck, 1822)

Ocinebrina aciculata (Lamarck, 1822) (Figs 1 A-H; 2 G, J)

Murex aciculatus Lamarck, 1822: 176

Murex corallinus Scacchi, 1836: 12.

Murex inconspicuus Sowerby G.B. II, 1834: 5 (67), Fig. 81.

Murex pistacia Reeve, 1845: plate XXXIV - species 174; Houart 2001: 70, Figs. 78-79 (2 syntypes figured).

Fusus acrisius Nardo, 1847: 59-60.

Fusus titii Stossich, 1865: 31

Murex subaciculatus Locard, 1886: 164.

Ocinebra wardiana Baker, 1891: 134, plate 11: Fig. 5; Vokes 1994: 120, Fig. 11 (holotype figured).

Ocinebrina (Corallinia) scaloropsis Settepassi, 1977 ex Monterosato ms.: VI, plate 2: Figs. 25-29.

Type material. Murex aciculatus: no type material present in MNHN or in MHNG (Y. Finet, pers. comm.). Murex corallinus: neotype here designated (MZN Z7010) (Figs. 1 G, H). Murex inconspicuus: no type material present in NHMUK (R. Houart, unpublished data). Murex pistacia: 3 syntypes (NHMUK 1972021). Fusus acrisius: 14 syntypes (MSNVE 21980). Fusus titii: no type material present in MSNT (A. Colla, pers. comm.). Murex subaciculatus: not found. Ocinebra wardiana: holotype (CAS 20698). Ocinebrina (Corallinia) scaloropsis: not found.

Type localities. Murex aciculatus: near Vannes (France), Atlantic Ocean. Murex corallinus: off Cuma (Pozzuoli, Naples, Italy), Mediterranean. Murex inconspicuus: Jersey (English Channel), Atlantic
Ocean. Murex pistacia: unknown locality. Fusus acrisius: Gulf of Venice (Italy), Mediterranean. Fusus titii: northern Adriatic Sea, Mediterranean. Murex subaciculatus: Toulon (France), Mediterranean. Ocinebra wardiana: "Australia" (see discussion in Vokes 1994). Ocinebrina (Corallinia) scaloropsis: unknown locality.

Material examined. The available type material and specimens and shells from the Channel Islands, France, Spain, Portugal, the Azores, Madeira, the Canary Islands, Morocco, Italy, Tunisia, Malta, Slovenia, Croatia, Greece and Turkey (see details in Appendix B).

Distribution. Along the east Atlantic coasts up to Scilly and the Channel Islands to the north and up to Mauritania and northern Senegal to the south, including the Azores, Madeira, Selvagens and the Canary Islands, and presumably throughout the entire Mediterranean Sea (Houart 2001) (Fig. 3).

Morphology. Shell of medium size for the genus, TH up to $18 \mathrm{~mm}$, fusiform and solid. Protoconch paucispiral of 1.25-1.5 rounded whorls, globose, apparently smooth but with a microsculpture of small granules often arranged in spiral rows. Teleoconch uniformly pale brown, dark brown, reddish, pinkish or orangeish, occasionally black or white, usually of 6 convex whorls at maturity, slightly elongate and usually rounded, with the last whorl consisting of about $3 / 4$ of total height in adult specimens. Subsutural ramp rounded with impressed suture. Spiral sculpture in the convex part of the whorl consisting of 6 low, weakly squamose and rounded primary cords and approximately equally sized secondary cords. P1 and P2 start in the early teleoconch, IP starts at half of the first teleoconch whorl, while s1, s2 and abis start at half of the second teleconch whorl. Axial sculpture consisting of low, weak, broad, rounded ribs: $9-15$ on the first teleoconch whorl; $15-18$ on the second whorl; $13-16$ on the third whorl; 11-16 on the fourth whorl; $11-15$ on the fifth whorl; 9-13 on the last whorl. Outer lip weakly crenulate and with 5 weak to strong internal denticles (some could appear double), occasionally with a labral tooth, formed by the extension of P4. Labral varix slightly nodose, weak, narrow and rounded. Columellar lip moderately expanded ventrally, smooth, adherent adapically and slightly erect abapically. Aperture from narrow to moderately large, elongate-ovate, from pinkish to whitish coloured inside. Siphonal canal short, narrow, straight, ventrally sealed. Animal reddish. Operculum corneous from pale to dark brown, D-shaped/ovate, with subterminal nucleus surrounded by many concentric ridges. Radula typical of Ocenebrinae, with sickle-shaped lateral teeth with a broad base, rachidian bearing short and thick central and lateral cups with a short and thick inner lateral denticle on the base. Marginal area with short denticles and a thick marginal cusp.

Remarks. Shells of this species are easily diagnosed from most of the other Ocinebrina spp. by the rounded primary cords and equally sized secondary spiral cords 


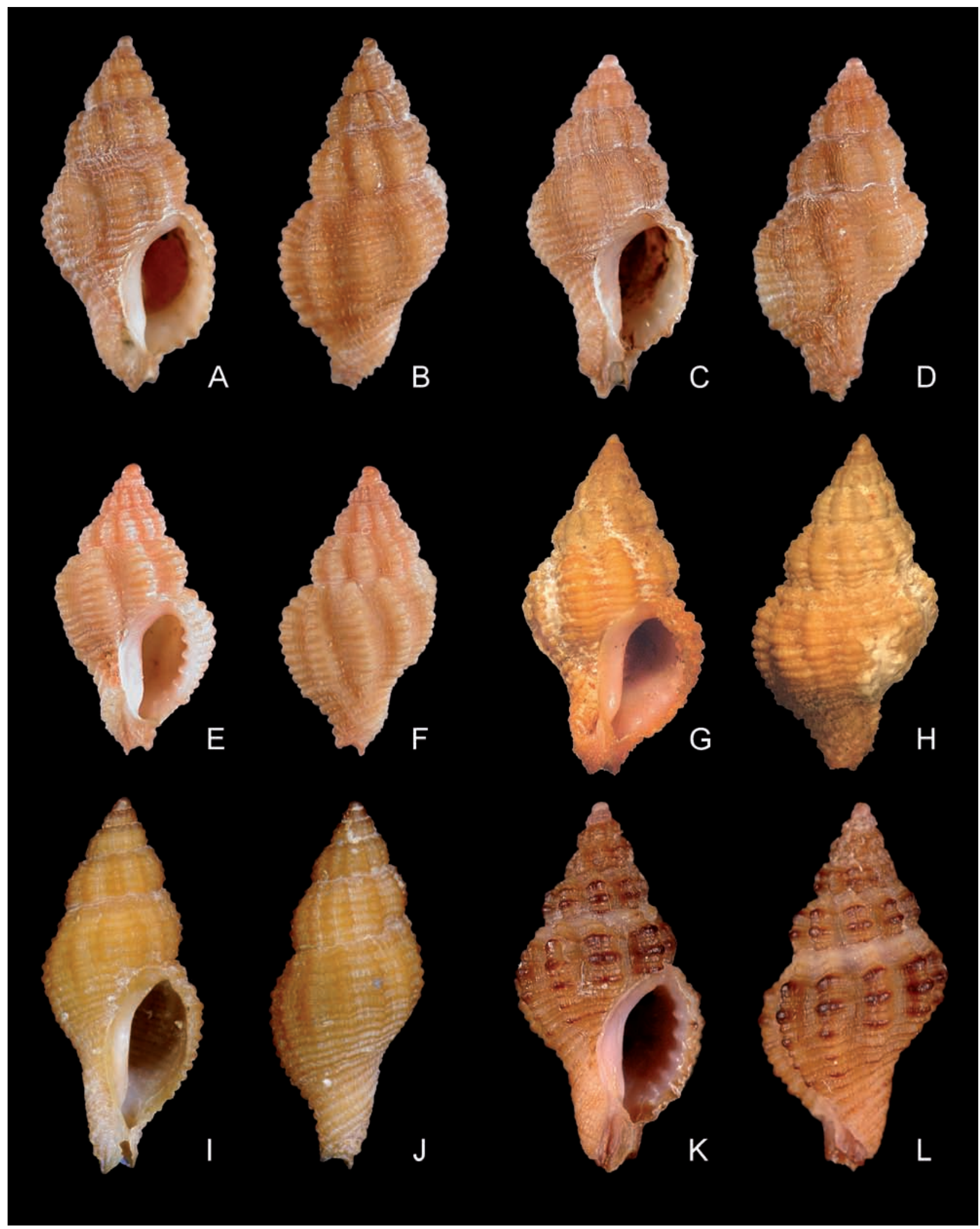

FIG. 1. - Shells of species of the Ocinebrina aciculata complex. A, B, O. aciculata, Erquy, Brittany, France (height $15.8 \mathrm{~mm}$ ), RHP; C, D, O. aciculata, Fuengirola, Spain (height $11.1 \mathrm{~mm}$ ), RHP; E, F, O. aciculata, Siracusa, Sicily, Italy (height $8.7 \mathrm{~mm}$ ), RHP; G, H, O. aciculata, Scacchetiello, Baia, Naples, Italy (height 11.9 mm), neotype of Murex corallinus Scacchi, MZN Z7010; I, J, O. corallinoides, Sfax, Tunisia (height $9.6 \mathrm{~mm}$ ), holotype of $O$. aciculata exilis Houart, MNHN 0362; K, L, O. reinai n. sp., Procida Island, Naples, Italy, holotype (height $9.9 \mathrm{~mm})$, MNHN 24566. 


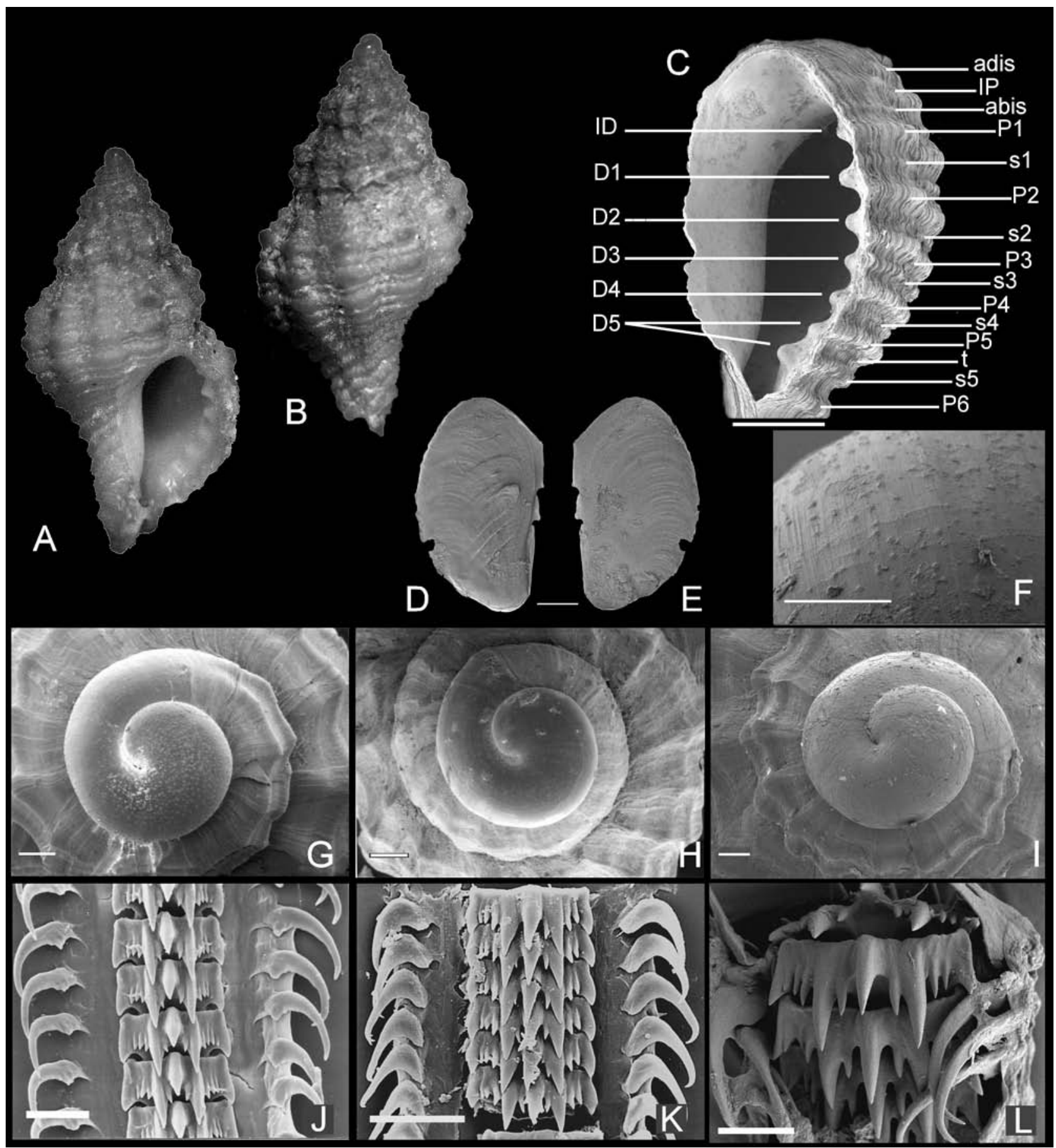

FIG. 2. - Shells and radulae of species of the Ocinebrina aciculata complex. A, B, O. reinai n. sp., Procida Island, GFP; C, O. reinai n. sp., Capraia Island, acronyms for primary and secondary spiral cords and threads (see text), FCP; D, E, O. reinai n. sp., Procida Island, operculum, paratype A, MZN Z7008; F, I, protoconch of $O$. reinai n. sp. Procida Island, FCP; G, protoconch of $O$. aciculata, Feteiras, RHP; H, protoconch of $O$. corallinoides, Sfax, RHP; J, radula of $O$. aciculata, Feteiras, RHP; K, radula of $O$. corallinoides, Sfax, RHP; L, radula of $O$. reinai n. sp. Procida Island, paratype A, MZN Z7008. Scale bars, $1 \mathrm{~mm}(\mathrm{C}), 500 \mu$ (D-E), $100 \mu$ (F-I), $50 \mu(\mathrm{J}-\mathrm{K}), 10 \mu$ (L).

(Houart 2001), a character shared only with Ocinebrina corallinoides Pallary, 1912 (see below). Similarly to most common and widespread northeastern Atlantic and Mediterranean species, the nomenclatural history of Ocinebrina aciculata is somewhat complicated by a long list of synonyms (see Houart 2001 and the Ap- pendix A herein for additional comments). Among the synonyms, Murex corallinus Scacchi, 1836 is the only taxon described from within the geographic range of the new species we describe herein (see below) that shows constant, yet subtle morphological differences from O. aciculata. The description of Murex corallinus 
Scacchi, 1836 was explicitly based on specimens with clean shells not incrusted by sponges (Scacchi 1836) and both the original description (no dark spots on the ribs) and the drawings (similarly sized primary and secondary spiral cords are evident) clearly indicate the typical Ocinebrina aciculata. As no type material of Murex corallinus Scacchi, 1836 (Cretella et al. 2005, N. Maio, pers. comm.) has been found to stabilize this synonymy, we have here designated as neotype a shell of $11.9 \times 6.5 \mathrm{~mm}$ (Figs. 1 G, H) from Scacchetiello (Baia, Naples) (MZN Z7010). Admittedly, a neotype selection for Murex aciculatus Lamarck, 1822 would also be desirable. However, given the evidence that in Ocinebrina some hidden biodiversity can be uncovered only with a genetic approach, we prefer to leave this designation to a future genetic and morphological revision of Ocinebrina aciculata throughout its entire range.

\section{Ocinebrina corallinoides Pallary, 1912} (Figs $1 \mathrm{I}, \mathrm{J}$; 2 H, K)

Ocinebrina corallinoides Pallary, 1912: 221, plate - Fig. 48. Ocinebrina aciculata corallinoides Nordsieck, 1968: 120, plate 19 - Fig. 71.11.

Ocinebrina aciculata exilis Houart, 2001: 62-63, Figs. 8-9, 167$168,324-325$

Ocinebrina buzzurroi Cecalupo and Mariani, 2008 in Cecalupo et al. 2008: 90-91, plate 43: Figs. 1-7.

Type material. Ocinebrina corallinoides: not found; Ocinebrina aciculata exilis: holotype (MNHN 0362) (Figs. 1 I, J); Ocinebrina buzzurroi: holotype (MNHM 33489).

Type localities. Ocinebrina corallinoides: near Sfax, Gulf of Gabès (Tunisia); Ocinebrina aciculata exilis: NW of Bou Grara Sea (Tunisia); Ocinebrina buzzurroi: Borj el Hissar (Tunisia).

Material examined. The available type material and specimens and shells from the Gulf of Gabès (Tunisia) (Kerkennah, Sfax, Djerba and Bou Grara) (see details in Appendix B).

Distribution. Currently known only from the Gulf of Gabès (Tunisia) (Pallary 1912, Houart 2001, Cecalupo et al. 2008) (Fig. 3).

Morphology. Shell of medium size for the genus, TH up to $14.2 \mathrm{~mm}$ at maturity, slender and lanceolate. Protoconch paucispiral of 1.5-1.75 rounded whorls, globose, apparently smooth but with weak, low, spiral threads. Teleoconch uniformly light tan, yellow-tan or pale brown, usually of 5 convex whorls at maturity, strongly elongate and weakly convex, with the last whorl consisting of about $1 / 2$ of total height in adult specimens. Subsutural ramp rounded with impressed suture. Spiral sculpture in the convex part of the whorl consisting of 6 low, weakly squamose and rounded primary cords and approximately equally sized secondary cords, and occasionally smaller threads. P1 and P2 start in the early teleoconch with P1 always weak and low. IP starts on the second whorl, soon followed by s1, s2 and abis. Axial sculpture consisting of low, weak, broad, rounded ribs: $15-16$ on the first whorl; $13-17$ on the second whorl; $12-15$ on the third whorl; 14 on the fourth whorl; 9-11 on the last whorl. Outer lip weakly crenulate and with 5 weak internal denticles (some could appear double), and with an occasional labral tooth, formed by the extension of P4. Labral varix low, shallow, delicate. Columellar lip flaring, smooth; rim partially erect, adherent at adapical extremity. Aperture pale, moderately large and ovate. Siphonal canal short, narrow, straight, ventrally sealed. Animal reddish, with sparse whitish or yellowish speckles. Operculum corneous, brown, Dshaped/ovate, with subterminal nucleus, surrounded by concentric ridges. Radula typical of Ocenebrinae, with sickle-shaped lateral teeth with a broad base, rachidian bearing elongate, but quite thick, central and lateral cups with an elongate inner lateral denticle on base. Marginal area with short denticles and a thick marginal cusp.

Remarks. December 15, 1912 is the date of publication of $O$. corallinoides as reported into the original frontispiece, and not 1910 or 1920 as erroneously reported elsewhere (see Bonomolo and Buzzurro 2006, Cecalupo et al. 2008, Bank and Menkhorst 2009). This taxon was then reported and illustrated as subspecies of $O$. aciculata by Nordsieck (1968), who assigned it to Monterosato, following Pallary (1912), who probably referred to a name in Monterosato's manuscript. In the last revision of the European Muricidae, this taxon was rediscovered and described as $O$. aciculata exilis Houart, 2001 (see Houart 2001). Because of the reported co-occurrence of specimens of $O$. aciculata (Lamarck, 1822) in the Gulf of Gabès (Pallary 1912; Cecalupo et al. 2008) and to its peculiar morphological and radular features, $O$. aciculata exilis was raised to species level and then synonymized with Ocinebrina corallinoides Pallary, 1912 (Bonomolo and Buzzurro 2006; Cecalupo et al. 2008). Finally, Cecalupo and Mariani (in Cecalupo et al. 2008) described $O$. buzzurroi, from Sfax, which was evidently based on juveniles of $O$. corallinoides. The reported diagnostic features are mostly size-related (smaller size, fewer whorls), the results of miscounting (more numerous axial ribs), or within the range of variation of $O$. corallinoides (stronger $\mathrm{P} 4$, ending with a labral tooth, thicker shell).

Ocinebrina reinai Bonomolo and Crocetta n. sp. (Figs $1 \mathrm{~K}, \mathrm{~L}$; 2 A-F, I-L)

?Ocinebrina aciculata corallinoides sensu Parenzan 1970: p. 167, Fig. 648 (not Ocinebrina corallinoides Pallary, 1912).

Ocinebrina helleri (Brusina, 1865) sensu Houart 2001 (in part): 180 , Figs. 344, 345, 346, 347 only (not Fusus helleri Brusina, 1865). Ocinebrina nicolai (Monterosato, 1884) sensu Giannuzzi-Savelli, Pusateri, Palmeri and Ebreo 2003: Figs. 105a, 105b, 105c (not Ocinebrina nicolai Monterosato, 1884).

Ocinebrina aciculata (Lamarck, 1822) sensu Giannuzzi-Savelli, Pusateri, Palmeri and Ebreo 2003 (in part): 61, Fig. 84 only.

Ocinebrina aciculata (Lamarck, 1822) sensu Albano and Sabelli 2009 (in part?): 61 (upper image only?) (not Murex aciculatus Lamarck, 1822). 


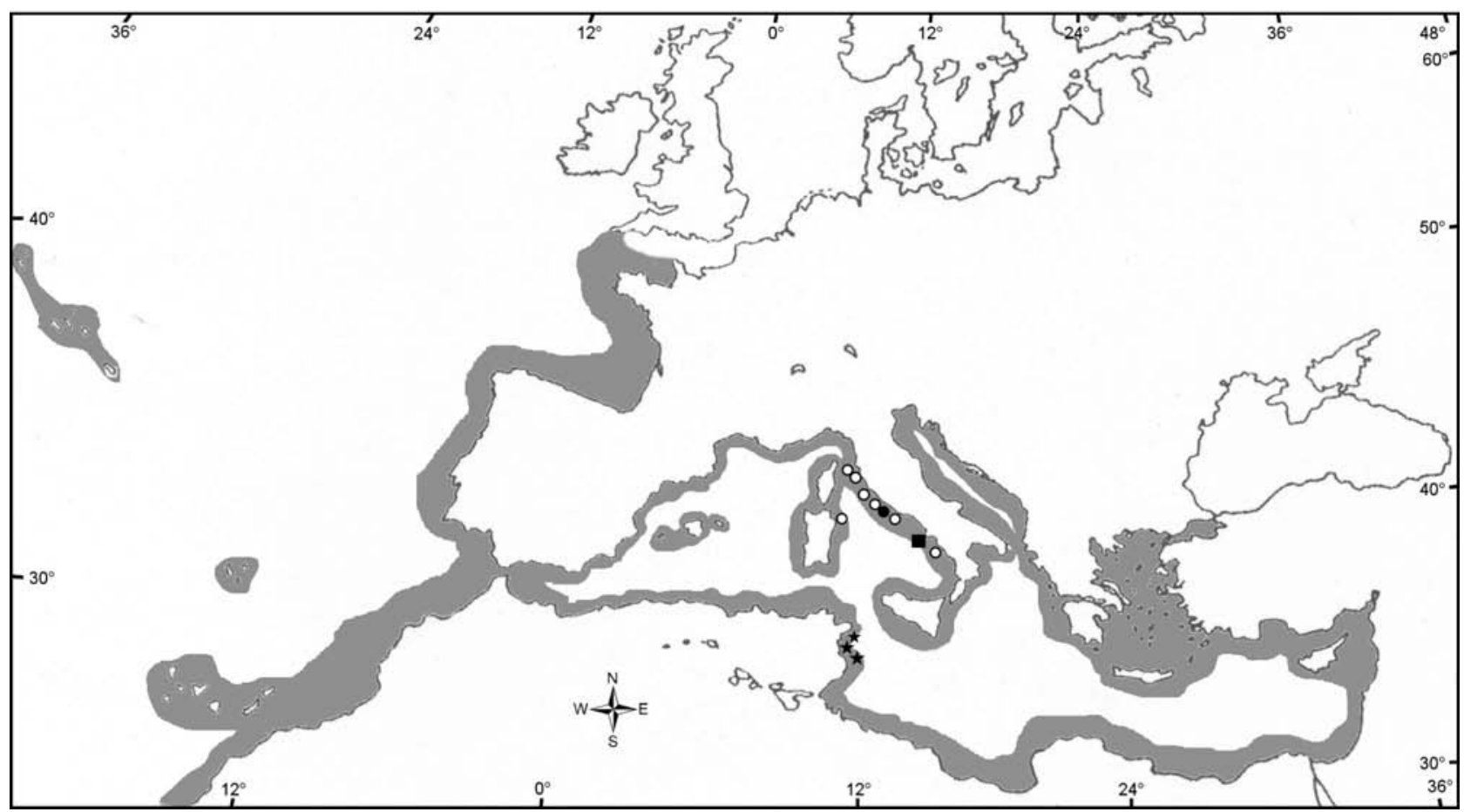

FIG. 3. - Distribution of the species of the $O$. aciculata complex. O. aciculata, shaded area. O. corallinoides, stars. O. reinai n. sp., circles; square, Procida Island, type locality; closed circle, Secche di Tor Paterno, sampling locality for the genetic study.

Type material. Holotype: Procida Island, $40^{\circ} 46^{\prime} \mathrm{N}, 014^{\circ} 01^{\prime} \mathrm{E}$ : MNHN 24566, lv $(9.9 \times 5.1 \mathrm{~mm}), 40 \mathrm{~m}$ depth, September 2010, F. Crocetta leg. (Figs. $1 \mathrm{~K}, \mathrm{~L}$ ); Paratypes: A: Procida Island, $40^{\circ} 46^{\prime}$ 'N, $014^{\circ} 01^{\prime} \mathrm{E}, \mathrm{MZN} \mathrm{Z7008}, 1 \mathrm{dd}(8.8 \times 4.5 \mathrm{~mm})$ and radula and operculum mounted and coated, $40 \mathrm{~m}$ depth, September 2010, F. Crocetta leg.; B: Gulf of Naples, SZN MOL 677, 1 dd $(9.2 \times 4.9 \mathrm{~mm}), \mathrm{C}$ Praus Franceschini leg.; C: Gulf of Naples, SZN MOL 677, 1 dd $(9.1 \times 4.7 \mathrm{~mm})$, C. Praus Franceschini leg.; D: Gulf of Naples, SZN MOL 686, 1 dd $(8.4 \times 4.5 \mathrm{~mm})$, C. Praus Franceschini leg.; E: Gulf of Naples, SZN MOL 686, 1 dd $(8.5 \times 4.3 \mathrm{~mm})$, C. Praus Franceschini leg.; F: Gulf of Naples, SZN MOL 686, 1 dd $(6.1 \times 3.3 \mathrm{~mm})$, C. Praus Franceschini leg.

Type locality. Procida Island (Naples, Campania, Italy), 4046’ N, $014^{\circ} 01^{\prime} \mathrm{E}, 40 \mathrm{~m}$ depth.

Material examined. The type material and 25 specimens and 18 shells from Italy (Tuscany, Latium, Campania and Sardinia) (see details in Appendix B).

Description. Shell of medium size for the genus, TH up to $12.3 \mathrm{~mm}$ and TW $5.5 \mathrm{~mm}(9.9 \times 5.1$ in the holotype), fusiform, solid and with slightly scalariform appearance. Protoconch paucispiral of 1.5-1.75 rounded whorls (1.75 in the holotype), amber in colour, globose, apparently smooth but with a microsculpture of several irregularly-shaped granules, $\mathrm{ca}$. $10 \mu \mathrm{m}$ in diameter. Weak growth lines and horizontal veins sometimes present only in very well preserved specimens. Teleoconch uniformly pale brown, reddish or orange, occasionally with a very tiny, whitish spiral band in the median zone; dark spots on ribs, in proximity of the spiral cords, more evident in freshly collected specimens. Teleoconch of 4.5-5.5 convex whorls (5 in the holotype) at maturity, slightly elongated but rounded and broad in the median zone, with the last whorl consisting of $c a .2 / 3$ of TH. Subsutural ramp slightly angled, broad, with adpressed suture. Spiral sculpture in the convex part of the whorl consisting of 6 nodose and rounded primary cords stronger than secondary cords, and often smaller threads (present in the holotype). P1 and P2 start in the early teleoconch, IP on the second whorl, soon followed by s1, s2 and abis that can start from the second to the third whorl (holotype: s1 from the half of the second whorl, s2 and abis from the third whorl). Axial sculpture consisting of low, rounded and nodose ribs: 13-15 on the first teleoconch whorl; 10-13 on the second whorl; 10-11 on the third whorl; 9-11 on the fourth whorl; 8-10 on the last whorl (in the holotype: 13 on the first whorl, 11 on the second whorl; 10 on the third whorl; 10 on the fourth whorl; 9 on the last whorl). Outer lip crenulate, erect, with 5 internal denticles (sometimes one could appear double) and an additional ID on the ventral face of the infrasutural ramp (as in the holotype). The ID can be reduced, or occasionally absent in some specimens, as in the paratype A and in specimens with a not completely formed lip. Labral varix nodose, weak, narrow and rounded. Columellar lip slightly expanded ventrally, smooth, adherent adapically and weakly erect abapically. Aperture moderately narrow, elongate-ovate, lucid, pale violet. Labral tooth, formed by the extension of P4, rarely present (absent in the holotype). Siphonal canal moderately long for the genus, ventrally sealed and dorsally spirally sculptured. Animal reddish. Operculum corneous from pale to dark brown, D-shaped/ovate, with subterminal nucleus surrounded by many concentric ridges. 


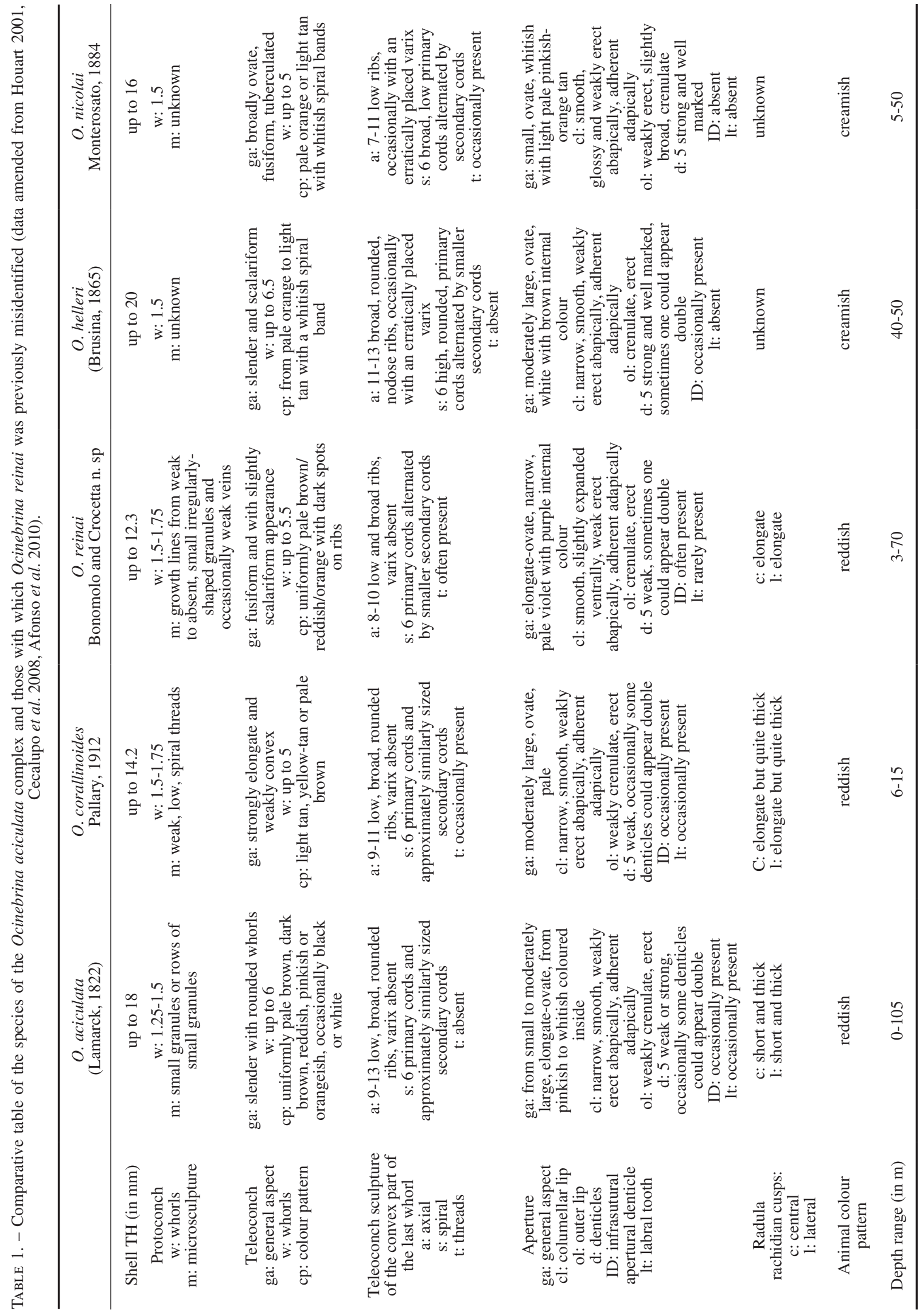


TABLE 2. - DNA diversity in sympatric samples of Ocinebrina aciculata and O. reinai.

\begin{tabular}{lccc}
\hline Species & $\mathrm{N}$ & $\begin{array}{c}\text { Haplotypes } \\
\text { and haplotype } \\
\text { diversity - Hd }\end{array}$ & $\begin{array}{c}\text { Nucleotide } \\
\text { diversity - } \pi\end{array}$ \\
\hline O. aciculata (Lamarck, 1822) & 8 & 6 & $\begin{array}{c}\text { Mean genetic } \\
\text { distance - K2P } \\
\text { O. reinai Bonomolo and Crocetta n. sp. }\end{array}$ \\
\end{tabular}

Internal surface usually with 3 or 4 growth lines and a callous rim. Radula typical of Ocenebrinae, with sickle-shaped lateral teeth with a broad base, rachidian bearing elongated central and lateral cups, with very elongated inner lateral denticle on base. Marginal area with short denticles and a thick marginal cusp.

Etymology. Named after Michele Reina (Palermo, Italy), Sicilian malacologist, palaeontologist and naturalist.

Distribution. The species is currently known from the central Mediterranean Sea, from $43^{\circ} 33^{\prime} \mathrm{N}$ to $40^{\circ} 34^{\prime} \mathrm{N}$ and from $010^{\circ} 13^{\prime} \mathrm{E}$ to $014^{\circ} 12^{\prime} \mathrm{E}$ (Fig. 3). At Procida Island (type locality), where most observations were carried out, it is rather common at depths from $20 \mathrm{~m}$ down to $c a .40 \mathrm{~m}$, with rare specimens collected alive up to $3 \mathrm{~m}$ and down to $c a$. $70 \mathrm{~m}$ depth. The specimen figured by Giannuzzi-Savelli et al. (2003: Figs. $105 \mathrm{a}, 105 \mathrm{~b}, 105 \mathrm{c}$, as $O$. nicolai) is stated to come from Malaga (southern Spain), where despite extensive surveys $O$. reinai has never been found. We therefore prefer to keep that record as likely erroneous.

Remarks. Ocinebrina reinai is clearly part of the $O$. aciculata complex, given the similar shell shape (with rounded teleoconch whorls and occasional presence of labral tooth) and the reddish colour of the animal, but it also resembles $O$. helleri and $O$. nicolai in the spiral sculpture. In fact, it has been misidentified under all these names in the recent literature (see synonymies). It mainly differs from $O$. aciculata and $O$. corallinoides in 2 constant teleoconch features: the dark spots on the ribs, more evident in living specimens, and the spiral sculpture, with differently sized primary and secondary cords and smaller threads. It also differs from $O$. nicolai in the absence of nodose varices and the presence of low and weak ribs, the occasional presence of ID and labral tooth, the spiral sculpture, the dark spots on the ribs and the reddish colour (whitish in O. nicolai) of the animal (Houart 2001, Bonomolo and Buzzurro 2006, Afonso et al. 2010); and from $O$. helleri in the less rounded whorls, the weaker spiral sculpture, the occasional presence of ID and labral tooth, the absence of spinelets on labral varix, the dark spots on the ribs, and the reddish colour of the animal (whitish in $O$. helleri) (Houart 2001, Bonomolo and Crocetta, unpublished data). In Table 1 differences from these congeneric species are summarized.
A muricid taxon from Capri, apparently named in schedis by Monterosato, was listed by Praus Franceschini (1906) as Ocinebrina bellini and by Bellini (1929) as Ocinebrina aciculata var. bellinii. These names were never accompanied by a valid description, and thus remain nomina nuda (ICZN, 1999: Art. 12 and Glossary). No material is preserved at MZN with this name (N. Maio, pers. comm.), but 2 specimens of $O$. reinai were deposited at SZN by Praus Franceschini under the name Tritonalia (Ocinebrina) aciculata var. bellinii (MOL 677). However, the 3 specimens deposited as Tritonalia (Ocinebrina) aciculata (MOL 686) by the same Praus Franceschini also belong to $O$. reinai, and thus there is no certainty that a name in honour of Bellini was used, in the past, to unequivocally identify the new species. Finally, $O c$ inebrina reinai was presumably described and figured by Parenzan (1970) as Ocinebrina aciculata corallinoides (Monterosato), a junior primary homonym of Ocinebrina corallinoides Pallary, 1912, and by Settepassi (1977) as Ocinebrina nicolai forma longicauda, an infrasubspecific rank name and thus not available (ICZN, 1999: Art. 45.5, 45.6).

\section{MOLECULAR TAXONOMY}

Partial sequences of the mtDNA encoding the COI were obtained from 16 specimens, collected at a single locality in the central Tyrrhenian Sea and morphologically ascribed to $O$. aciculata (Lamarck, 1822) (8 spms) and $O$. reinai Bonomolo and Crocetta n. sp. (8 spms). The sequences have been deposited at the European Molecular Biology Laboratory (EMBL - Accession numbers Ocinebrina aciculata: FR851899-FR851906; Ocinebrina reinai: FR851907-FR851914). A total of 658 bp were unambiguously aligned, without gaps, with 53 variable positions, resulting in 10 distinct haplotypes (total haplotype diversity, Hd: 0.9; total nucleotide diversity, $\pi$ : 0.03849: see Table 2 for values of each species). Six haplotypes were exclusive of $O$. aciculata and 4 of $O$. reinai, without shared haplotypes, and with one distinct network of haplotypes for each species (Fig. 4).

The mean genetic distance $(\mathrm{K} 2 \mathrm{P})$ within each species was 0.003 (SD 0.001) in O. aciculata, and 0.002 (SD 0.001) in $O$. reinai. The distance between the 2 species was 0.072 (SD 0.011), with an Fst of 0.965 (Hudson et al. 1992). A neighbour-joining tree portraying the genetic distance between each individual sequence is reported in Figure 4. 


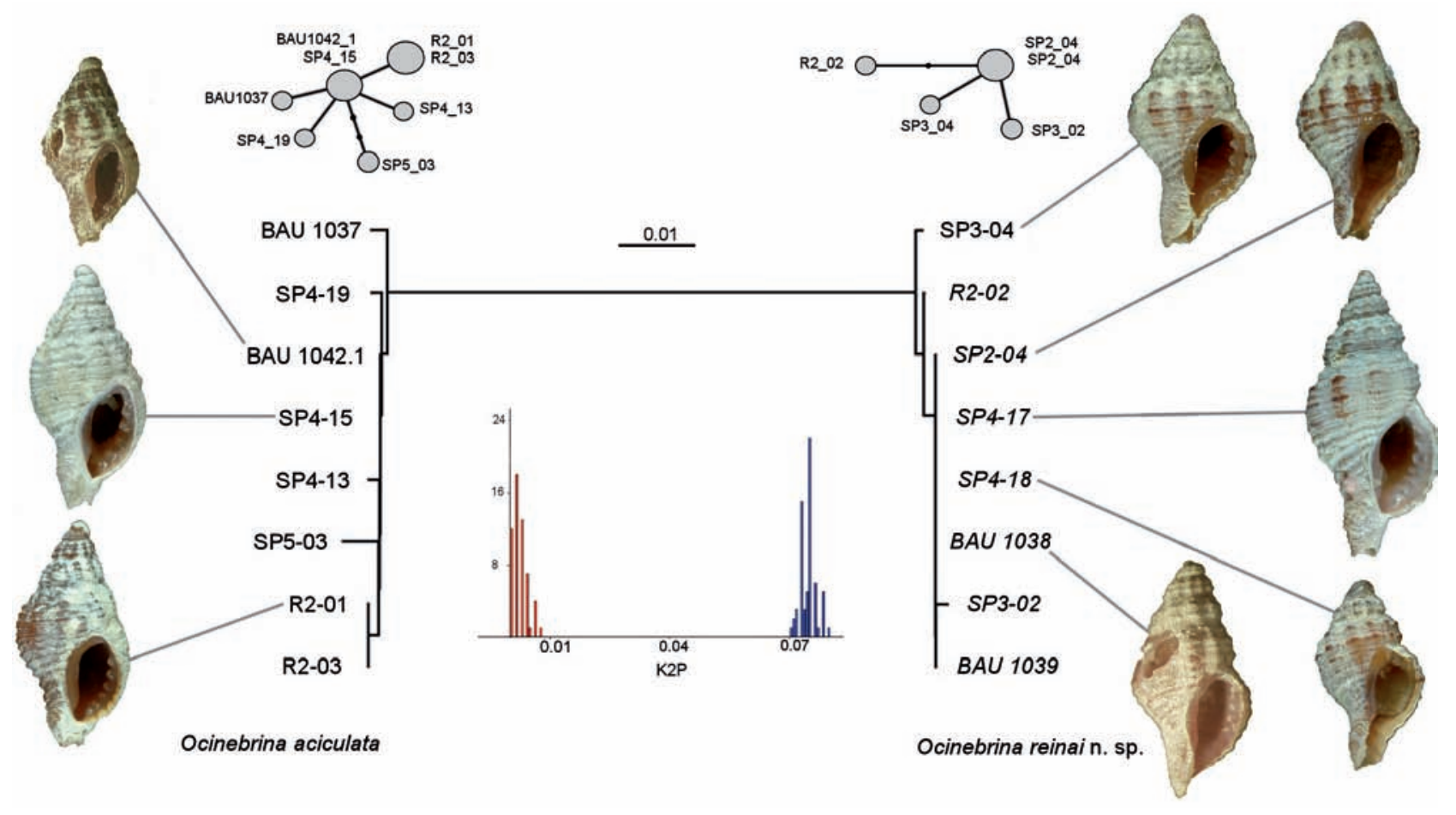

FIG. 4. - Neighbor-joining tree for specimens of $O$. aciculata and O. reinai n. sp. from Secche di Tor Paterno (Central Tyrrhenian Sea). Scale bar: $1 \% \mathrm{~K} 2 \mathrm{P}$ genetic divergence. Histograms report K2P genetic divergence in intraspecific (left) and interspecific (right) comparisons. Network of haplotypes based on statistical parsimony analysis.

\section{DISCUSSION}

Recent estimates report approximately 17000 species of marine organisms in the Mediterranean, and molluscs are one of the most diverse group $(12.4 \%)$ in term of species number (Coll et al. 2010). The marine mollusc fauna of the Mediterranean Sea is commonly considered as the best known in the world (Oliverio 2003). Nevertheless, the pace at which new taxa are discovered and described every year is still remarkably high. During the last 10 years (2001-2010), a total of 103 new species of molluscs have been described from the Mediterranean Sea (S. Gofas and M. Oliverio, unpublished data). The large majority of these new taxa have been described solely on the basis of morphology, and also in the present case $O$. reinai n. sp. was initially differentiated by morphological traits only from the very similar $O$. aciculata. The genetic divergence found between strictly sympatric samples of the 2 species in the COI fragment used as DNA barcode (over 7\%) is well over the threshold commonly accepted for species distinction (i.e. $>3 \%$ : Hebert et al. 2003). Nevertheless, in many cases, intra- vs. interspecific morphological variation is hardly separated, and genetic data can be crucial. The ongoing research with a combined study by morphology and molecular taxonomy of the small Ocinebrina species of the northeastern Atlantic and Mediterranean Sea (this study and unpublished data from the authors and M. Oliverio's laboratory) is also revealing an unexpected diversity with interesting biogeographic implications, definitively addressing the need for a thorough redefinition of the patterns of diversity of northeastern Atlantic and Mediterranean muricids.

\section{ACKNOWLEDGEMENTS}

We thank all colleagues who provided samples and bibliography for this study, in particular: Silvia Alfinito (Rome, Italy), Darija Caleta (Zagreb, Croatia), Miquel Capdevila (Reus, Spain), Paolo Crovato (Naples, Ita1y), Sergio Duraccio (Naples, Italy), Giuseppe Fasulo (Naples, Italy), Bruno Fumanti (Rome, Italy), Walter Renda (Amantea, Italy), Paolo Russo (Venice, Italy), Paolo Sordino (Naples, Italy) and Ermanno Quaggiotto (Longare, Italy). Franco Iamunno (Naples, Italy), Francesco Toscano (Naples, Italy), Anders Warén (Stockholm, Sweden) and Julien Cillis (Brussels, Belgium) are thanked for the SEM photographs; Serge Gofas (Malaga, Spain) provided unpublished data on the new species described from the Mediterranean Sea; and Flegra Bentivegna (Naples, Italy), Andrea Colla (Trieste, Italy), Yves Finet (Geneva, Switzerland), Gerardo Gustato (Naples, Italy), Nicola Maio (Naples, Italy), Luca Mizzan (Venice, Italy), Andrea Travaglini (Naples, Italy) and Cecilia Vianello (Venice, Italy) allowed consultation or provided information regarding museum collections. The first author thanks his family for their continuous support. 


\section{REFERENCES}

Albano P.G., Sabelli B. 2009. I Molluschi delle secche di Tor Paterno. Gli studi e le guide di RomaNatura, 2. Ente Regionale RomaNatura, Roma.

Afonso C.M.L., Bonomolo G., Monteiro P., Bentes L., Oliveira F. Veiga P., Rangel M.O., Sousa I., Leita L., Gonçalves J.M.S. 2010. First record of Ocinebrina nicolai (Mollusca: Gastropoda: Muricidae: Ocenebrinae) in north-eastern Atlantic waters. Mar. Biodiver. Rec. 3: e96: 1-4.

Baker F.C. 1891. Descriptions of new species of Muricidae, with remarks on the apices of certain forms. Proc. Rochester Acad. Sci. 1: 129-137.

Bank R.A., Menkhorst H.P.M.G. 2009. A revised bibliography of the malacological papers of Paul Pallary. Zool. Med. 83: 537-546.

Basterot de B. 1825. Description géologique du bassin tertiaire du Sud-Ouest de la France, (avec) description des coquilles fossiles des environs de Bordeaux. Mém. Soc. Hist. nat. Paris 2: 1-100.

Bellini R. 1929. I molluschi del Golfo Napoli (Studi precedenti, l'ambiente, enumerazione e sinonimia). Ann. Mus. Zool. R. Univ. Napoli 6: 1-87.

Bonomolo G., Buzzurro G. 2006. Description of a new Muricid for the Mediterranean sea: Ocinebrina paddeui (Mollusca, Gastropoda, Muricidae, Ocenebrinae). Triton 13: 1-4.

Brander G. 1766. Fossilia Hantoniensia Collecta, Et In Musaeo Britannico Deposita. London.

Brown T. 1827. Illustrations of the recent Conchology of Great Britain and Ireland. Lizars W.H. and Lizars D., Edinburgh.

Brusina S. 1865. Conchiglie dalmate inedite. Verh. Zool.-Bot. Ges. Wien 15: 3-42.

Bucquoy E.J., Dautzenberg Ph., Dollfus G.F. 1882. Les Mollusques marins du Roussillon. Tome I (Gastropodes). Baillière J.B. and Fils, Paris.

Cecalupo A., Buzzurro G., Mariani M. 2008. Contributo alla conoscenza della malacofauna del Golfo di Gabès (Tunisia). Quad. Civ. Staz. Idrob. Milano 31: 1-267.

Coen G.S. 1914. Contributo allo studio della Fauna malacologica Adriatica. R. Com. Tal. Ital., Mem. 46: 1-34.

Coen G.S. 1933. Saggio di una Sylloge Molluscorum Adriaticorum. R. Com. Tal. Ital. Mem. 192: 1-186.

Coll M., Piroddi C., Steenbeek J., Kaschner K., Lasram F.B.R., Aguzzi J., Ballesteros E., Bianchi C.N., Corbera J., Dailianis T., Danovaro R., Estrada M., Froglia C., Galil B., Gasol J.M., Gertwagen J., Gil J., Guilhaumon F., Kesner-Reyes K., Kitsos M.S., Koukouras A., Lampadariou N., Laxamana E., de la Cuadra C.M.L., Lotze H.K., Martin D., Mouillot D., Oro D., Raicevich S., Rius-Barile J., Saiz-Salinas J.I., San Vicente C., Somot S., Templado J., Turon X., Vafidis D., Villanueva R., Voultsiadou E. 2010. The Biodiversity of the Mediterranean Sea: Estimates, Patterns, and Threats. PLoS One 5: e11842.

Cretella M., Crovato C., Crovato P., Fasulo G., Toscano F. 2005. L'opera malacologica di Arcangelo Scacchi (1810-1893). Parte II: rassegna critica dei taxa scacchiani. Boll. Malac. 40: 114-131.

Deshayes G.P. 1833. Mollusques In: J.B.G.M. Bory de Saint Vincent, 1832-1836: Expédition scientifique de Morée (4 vols. and atlas), section des sciences physiques 3(1) - Zoologie. Première section. Animaux vertébrés, mollusques et polypiers. F.G. Levrault, Paris, pp. 81-205, pls 18-26.

Folmer O., Black M., Hoeh W., Lutz R., Vrijenhoek R. 1994. DNA primers for amplification of mitochondrial cytochrome c oxidase subunit I from diverse metazoan invertebrates. Mol. Mar. Biol. Biotechnol. 3: 294-299.

Giannuzzi-Savelli R., Pusateri F., Palmeri A., Ebreo C. 2003. Atlante delle conchiglie marine del Mediterraneo. Vol. 4 (Neogastropoda: Muricoidea). Edizioni Evolver, Roma.

Hebert P.D.N., Ratnasingham S., deWaard J.R. 2003. Barcoding animal life: cytochrome c oxidase subunit 1 divergences among closely related species. Proc. R. Soc. Lond. B 270: S96-99.

Houart R. 2001. A review of the recent Mediterranean and Northeastern Atlantic species of Muricidae. Edizioni Evolver, Roma.

Hudson R.R., Slatkin M., Maddison W.P. 1992. Estimation of levels of gene flow from population data. Genetics 132: 583-589.

Jeffreys J.G. 1867. British Conchology, or an account of the Mollusca which now inhabit the British isles and the surrounding seas. Vol. IV. Marine Shells. J. van Voorst, London.

Jobb G. 2008. "Treefinder version of April 2008", Software distributed by the author at http://www.treefinder.de/.

Jousseaume F.P. 1880. Division méthodique de la famille des Purpuridae. Le Naturaliste: journal des échanges et des nouvelles 2: 335-336.

Lamarck J.B.M. 1822. Histoire naturelle des animaux sans vertèbres, présentant les caractères généraux et particuliers de ces animaux, leur distribution, leurs classes, leurs familles, leurs genres, et la citation des principales espèces qui s'y rapportent; précédée d'une introduction offrant la détermination des caractères essentiels de l'animal, sa distinction du végétal et des autres corps naturels; enfin, l'exposition des principes fondamentaux de la zoologie. Vol. 7. Paris.

Librado P., Rozas J. 2009. DnaSP v5: A software for comprehensive analysis of DNA polymorphism data. Bioinformatics 25: $1451-1452$.

Locard A. 1886. Prodrome de malacologie française. Vol. 2. Catalogue général des Mollusques vivants de France. Mollusques marins. Librairie Henri Georg, Lyon.

Merle D. 2001. The spiral cords and the internal denticles of the outer lip in the Muricidae: terminology and methodological comments. Novapex 2: 69-91.

Merle D. 2005. The spiral cords of the Muricidae (Gastropoda, Neogastropoda): importance of ontogenetic and topological correspondences for delineating structural homologies. Lethaia 38: $367-379$

Montagu G. 1808. Testacea Britannica or natural history of British shells, marine, land and fresh-water. Supplement. Hollis e Romsey, London.

Monterosato T. di Maria. 1872. Notizie intorno alle conchiglie mediterranee. Ufficio Tipografico di Michele Amenta, Palermo.

Monterosato T. di Maria. 1884. Nomenclatura generica e specifica di alcune conchiglie mediterranee. Stabilimento Tipografico Virzì, Palermo.

Nardo G.D. 1847. Sinonimia moderna delle specie registrate nell' opera intitolata: Descrizione de' crostacei, de' testacei e de' pesci che abitano le lagune e golfo veneto, rappresentati in figure, a chiaro-scuro ed a colori dall' Abate Stefano Chiereghini Ven. Clodiense. Venezia.

Nordsieck F. 1968. Die europäischen Meeres-Gehäuseschnecken (Prosobranchia). G. Fischer, Stuttgart.

Oliverio M. 2003. The Mediterranean molluscs: the best known malacofauna of the world... so far. Biogeographia 24: 195-208.

Oliverio M., Mariottini P. 2001. A molecular framework for the phylogeny of Coralliophila and related muricoids. J. Moll. Stud. 67: 215-224.

Pallary P. 1912. Sur la faune de l'ancienne lagune de Tunis. Bull. Soc. Hist. nat. Afr. Nord 3: 215-228.

Pallary P. 1920. Mission zoologique. Malacologie. In: Exploration scientifique du Maroc organisée par la Société de Géographie de Paris et continuée par la Société des Sciences Naturelles du Maroc. Deuxième fascicule. Institut Scientifique Chérifien, Rabat/Paris

Parenzan P. 1970. Carta d'identità delle conchiglie del Mediterraneo I vol.: Gasteropodi. Bio Taras Editrice, Taranto.

Philippi R.A. 1836. Enumeratio molluscorum Siciliae cum viventium tum in tellure tertiaria fossilium, quae in itinere suo observavit. Vol. 1. Schropp, Berlin.

Praus Franceschini C. 1906. Elenco delle conchiglie del Golfo di Napoli e del Mediterraneo esistenti nel Museo Zoologico di Napoli. Ann. Mus. Zool. Univ. Napoli 2: 1-68.

Reeve L.A. 1845. Conchologia Iconica, or, illustrations of the shells of Molluscous animals. Vol. 3. London.

Scacchi A. 1836. Catalogus Conchyliorum Regni Neapolitani quae usque adhuc reperit A. Scacchi. Typis Filiatre-Sebetii, Neapoli.

Settepassi F. 1977. Atlante Malacologico dei Molluschi marini viventi nel Mediterraneo. II. Gasteropodi. Roma.

Sowerby J.D.C. 1825. The mineral conchology of Great Britain; or coloured figures and descriptions of those remains of testaceous animals or shells, which have been preserved at various times and depths in the earth. Vol. 5(84-85): 139-144, pls 486491 [84], 145-152, pls 492-497 [85]. London.

Sowerby G.B. II. 1832-1841. The conchological illustrations, or coloured figures of all the hitherto unfigured Recent shells. London

Stossich A. 1865. Enumerazione dei Molluschi del Golfo di Trieste. 
Programma della Civica Scuola Reale Superiore di Trieste: $21-58$.

Swofford D.L. 2002. PAUP*. Phylogenetic Analysis Using Parsimony (*and Other Methods).

Tamura K., Dudley J., Nei M., Kumar S. 2007. MEGA4: Molecular Evolutionary Genetics Analysis (MEGA) software version 4.0. Mol. Biol. Evol. 24: 1596-1599.

Tamura K., Peterson D., Peterson N., Stecher G., Nei M., Kumar S. 2011. MEGA5: Molecular Evolutionary Genetics Analy- sis using Maximum Likelihood, Evolutionary Distance, and Maximum Parsimony Methods. Mol. Biol. Evol.: in press. doi: $10.1093 / \mathrm{molbev} / \mathrm{msr} 121$.

Vokes E.H. 1994. The muricid types of Frank Collins Baker. The Nautilus 107: 118-123.

Scient. ed.: J. Templado.

Received April 11, 2011. Accepted September 12, 2011.

Published online January 2, 2012.

APPENDIX A. - Additional nomenclatural notes on Ocinebrina aciculata (Lamarck, 1822)

Several authors reported Fusus gyrinus Brown, 1827 among the synonyms of $O$. aciculata, but Brown (1827) was referring to Murex gyrinus Montagu, 1808. Montagu (1808) originally referred to Murex gyrinus Linnaeus, 1758, a Ranellidae, Gyrineum gyrinum (Linnaeus, 1758). The same holds for Fusus lavatus Philippi, 1836. Philippi (1836) was referring his living O. aciculata to Fusus lavatus as figured in Basterot (1825), which may or may not be a fossil specimen of Ocinebrina aciculata from the "bassin tertiaire du sudouest de la France". Unfortunately, the same Basterot (1825) was originally referring to Buccinum lavatum Brander (1766) and to Sowerby J.D.C. (1825), that clearly were using the name for a buccinid or a fasciolariid, not a Muricidae. Neither Basterot's nor Philippi's use of lavatum could thus result in a valid name for whatever species. Fusus minutus Deshayes, 1833 has been indicated as a junior synonym of $O$. aciculata (Lamarck, 1822). Deshayes (1833) was actually referring to Fusus minutus Lamarck, 1803 from the Eocene of Paris, which is, however, invalid as a junior primary homonym of the buccinid Fusus minutus Röding, 1798. Murex badius Reeve, 1845, described with unknown distributional data, has been often reported as a junior synonym of $O$. aciculata (Lamarck, 1822). It is now Orania badia (Reeve, 1845). Murex aciculatus var. badia Jeffreys, 1867, Ocinebrina corallina var. major Pallary, 1900, Ocinebra (Ocinebrina) pseudoscalaris Coen, 1914, Ocinebra (Ocinebrina) corallinum var. scalariformis Coen, 1914, Ocinebra (Ocinebrina) corallinum var. atra Coen, 1914, Ocinebra (Corallinia) aciculatum var. scalariformis Coen, 1933 are nomina nuda (ICZN, 1999: Art. 12 and Glossary). Murex aciculatus var. curta Bucquoy, Dautzenberg and Dollfus, 1882 and Murex aciculatus var. minor Bucquoy, Dautzenberg and Dollfus, 1882, Ocinebrina aciculata var. cingulifera Pallary, 1920 and Ocinebrina aciculata var. elongata Pallary, 1920 have infrasubspecific rank and are thus not available (ICZN, 1999: Art. 45.5, 45.6). Other names, all manuscript names of Monterosato, introduced as varietal names (explicitly and as unambiguously revealed by the content of the work) by Settepassi (1977) have infrasubspecific rank and are thus also not available (ICZN, 1999: Art. 45.5, 45.6): Ocinebrina (Corallinia) titii minor, Ocinebrina (Corallinia) corallina elongata, Ocinebrina (Corallinia) corallina spongiderma and Ocinebrina (Corallinia) corallina scalariformis. Settepassi (1977) also figured and described specimens of $O$. aciculata as subspecies elongata and subspecies inflata of Ocinebrina halleriana [sic!], an unjustified emendation of Fusus helleri Brusina, 1865 = Ocinebrina helleri (Brusina, 1865). We feel that also for these names an infrasubspecific rank could be applied as unambiguously revealed by the content of the work (both are cited as found together with the nominotypical, so we could assume that Settepassi considered them as forms of $O$. helleri). In any case they would be invalid as junior synonyms of $O$. aciculata. In addition, Settepassi (1977) did not consistently use binomial nomenclature. Although there is not yet a specific decision of ICZN, there are precedents of works that were rejected on such grounds. 
APPENDIX B. - Additional material examined.

\section{Ocinebrina aciculata (Lamarck, 1822)}

Channel Islands: Guernsey, 3 lv (RHP).

France: Erquy, on harbour wall at very low tide, 6 lv (RHP), 3 lv, 3 dd (GBP); Le Verdelet, 3 lv (RHP); St. Lunaire, 3 lv (RHP); Roscoff, 5 lv (RHP). Corsica, region of Calvi, 1 lv, 1 dd (RHP); Calvi, many lv and dd (RHP); Barneville (Normandie), on rocks at low tide, 4 lv (GBP); L'Arcouest, on rocks at low tide, 2 lv (GBP); Paimpol, -15 m among oysters, 2 lv, 2 dd (GBP); Mont S. Michel, beach, 1 dd (GBP)

Spain: Vigo, on rocks, 5 lv (RHP); Ceuta, 9 lv (RHP); Ceuta, $-80 / 100 \mathrm{~m}$, fishing nets residuals, $4 \mathrm{lv}, 1 \mathrm{dd}$ (MOP); Alboran Is., $35^{\circ} 56^{\prime} 94^{\prime \prime} \mathrm{N} 003^{\circ} 00^{\prime} 90^{\prime \prime} \mathrm{E},-32 \mathrm{~m}$, bioclastic sands with Laminaria, 2 lv 10 dd (MOP); Alboran Is., 35'56'10”N 00301'48”E, -17 m, bioclastic sands, $10 \mathrm{dd}$ (MOP); Alboran Sea -80/100 m, 4 lv, $10 \mathrm{dd}$ (GBP); Algeciras, Cádiz, 3 lv (RHP); El Alquián, Almeria, Dishers, 3 lv (RHP); Almeria, trawlers, 3 lv (GBP); Fuengirola, in fisher nets, 20 lv (RHP); Marbella, 4 lv (RHP); Malaga, -6 m, 2 lv (GBP); Malaga, trawlers, $7 \mathrm{lv}, 2 \mathrm{dd}$ (GBP); Algesiras, $2 \mathrm{dd}$ (GFP); Torremolinos, - 2 m, 2 dd (PSP); Adra, Malaga, trawlers - 70 m, 8 lv (GBP); Amella de Mar, low depth, 1 lv (GBP).

Portugal: Amarção de Pera, Fisher boat, 7 lv (RHP); Sagres harbour, 3 lv (RHP), 2 lv (GBP); Olhão, -5/10 m, 3 lv (MOP), 5 lv (GBP); off Ponda da Piedade, Lagos, $-45 / 50 \mathrm{~m}$, octopus trap, $1 \mathrm{lv}$ (MOP) 9 lv (GBP), -50/80 m gill nets, 5 lv (GBP); Vilamoura, low depth, 4 lv (GBP); Catalazede Beach, Oeiras, Lisbona, beach, 9 dd (GBP); Burgau, gill nets on coralline bottom, $-45 / 50 \mathrm{~m}, 2$ lv (GBP).

Azores: Sao Miguel Is., Feteiras, 3 lv (RHP); Fajal Is., Ponta dos Capelinhos, intertidal, 1 dd (MOP).

Madeira: 2 lv, 6 dd (RHP).

Canary Islands: Lanzarote, Arrecife, 1 lv (RHP); Gran Canaria, Las Palmas, 1 lv (RHP); Tenerife, -3 m, 2 lv (GBP).

Morocco: Fedala, 2 dd (RHP); Rabat, 2 lv (RHP); Pointe Imessouane, beached, $1 \mathrm{dd}$ (MOP).

Italy: Giglio Island, - $60 \mathrm{~m}, 5 \mathrm{lv}$ (GBP); Tuscan Archipelago, trawlers, -70/80 m, 4 lv (GBP); Capraia, -50/60 m, 1 lv, 2 dd (GBP); La Maddalena, from fishermen, $-50 / 60 \mathrm{~m}, 3 \mathrm{lv}$ and $5 \mathrm{dd}$ (GBP); off Alghero, fishing net residuals, $-40 / 80 \mathrm{~m}, 4 \mathrm{lv} 4 \mathrm{dd}$ (MOP); Porto Torres, -40 m, 2 lv (GFP); Giannutri Is., Grottoni (42 $15^{\prime} \mathrm{N}$ 011 06 'E), -47 m, 7 dd (MOP); Ladispoli (Roma), beach, 3 dd (GBP); Fiumicino, trawlers, 3 lv, 2 dd (GBP); off Montalto di Castro, fishing net residuals, $-50 / 60 \mathrm{~m}, 1 \mathrm{lv}$ (MOP); "Secche di Tor Paterno" Marine Protected Area: Stn R2 (41 $366^{\prime} 13^{\prime \prime N}, 012^{\circ} 20^{\prime} 30^{\prime \prime E}$, Posidonia oceanica patches on hard substratum, foliar layer, $-24 \mathrm{~m}$ ); Stns SP4-SP5 (41 ${ }^{\circ} 36^{\prime} 13^{\prime}$ N, $12^{\circ} 20^{\prime} 30^{\prime \prime}$, P. oceanica field on soft substratum, rhizome layer, $-26 \mathrm{~m}$ ) S8, S9: 41 ${ }^{\circ} 36^{\prime} 18^{\prime \prime} \mathrm{N}-12^{\circ} 20^{\prime} 30^{\prime \prime}$ $\mathrm{E}$, horizontal hard coralligenous substratum with Eunicella spp., -25 $\mathrm{m}$, suction sampler, $8 \mathrm{lv}$ used for genetics (SP4-19, R2-03, SP4-15, SP4-13, SP5-03, R2-01, S8-BAU1037, S9-BAU-1042.1); Posillipo, beached, 12 dd (GFP); Secca di Miseno, gill nets, $-30 \mathrm{~m}, 1 \mathrm{dd}$ (PSP); Procida Island, shell grit, $-2 / 3 \mathrm{~m}, 9 \mathrm{dd}$ (PSP), $75 \mathrm{dd}$ (FCP), 94 dd (GFP), 4 dd (SDP), 4 dd (GBP); Vivara Island, -10/15 m, shell grit, 21 dd (FCP); Capri Island, 2 lv, $-10 \mathrm{~m}$, shell grit (GFP); Ischia Island, $-10 \mathrm{~m}, 1 \mathrm{dd}$ (PSP); Marina di Puolo, from fishermen, $56 \mathrm{lv}$ and dd (SDP); Li Galli/Vetara, - 39m: 1 dd (SDP); Catanzaro Lido, from fishermen, 2 lv (PSP); Monopoli, beached, 2 dd (PAP); Gallipoli, coralligenous, 4 lv (GFP); Porto Cesareo, from fishermen, 3 lv (PAP); Gallipoli, scuba diving -8/14 m, 1 lv (PAP); Messina,
Posidonia meadows -6/7 m, 6 lv (FCP); Messina, from fishermen, -80 m, 2 lv (GBP); Cannizzaro (Catania), - 40/45 m, 4 lv, $6 \mathrm{dd}$ (GBP); Pozzillo, scuba diving -10/20 m, 1 lv (PAP); Siracusa, $5 \mathrm{lv}$ (RHP), 7 dd (GFP); Acitrezza, -9/19 m, 5 lv (RHP); Brucoli, 8 lv and dd (RHP), 4 dd (GFP); Marettimo Is., -15/40 m, 3 dd (MOP); Favignana Is. - $15 / 30 \mathrm{~m}, 1$ dd (PAP); Golfo di Carini, from fishermen, -50/70 m, 41 lv, 14 dd (GBP); Grado, 3 lv (GBP); Chioggia, 1 lv (RHP), 1 lv (PAP); Lido di Venezia, -28 m, 2 lv, 1 dd (RHP); Falconara Marittima, Ancona, beach, 3 dd (GBP); Silvi Marina, Pescara, 2 dd (GBP); Cupra Marittima, beach, 2 dd (GBP).

Tunisia: Bizerta, 1 lv (GFP)

Malta: St. Julian's Bay, shell grit -15 m, 1 dd (PAP); Wied-izZurrieq, shell grit $-36 \mathrm{~m}, 1$ dd (PAP).

Slovenia: Punta Grossa, $-2 \mathrm{~m}$, on algae, 4 lv (GBP); Punta Grossa $-2 / 3$ m amidst Cystoseira, 4 lv (FCP); Portorose, shell grit, $1 \mathrm{dd}$ (GFP).

Croatia: Salvore, from fishermen, 14 lv, 7 dd (GBP); Salvore, from fishermen, $-20 \mathrm{~m}, 2 \mathrm{lv}$ (FCP); Spalato, from fishermen, - 60 m, 2 lv (GBP); Zadar, -1/5 m, under rocks, 2 lv (FCP); Rovinj, from fishermen, $1 \mathrm{lv}$ (PAP).

Greece: Saronikos Gulf, from fishermen, 2 dd (GBP). (GBP).

Turkey: Tenedos (Bozcaada), from fishermen, - $60 \mathrm{~m}, 3 \mathrm{lv}$

Ocinebrina corallinoides (Pallary, 1912)

Tunisia: Gulf of Gabès: Kerkennah, beach, 4 dd (GFP); Sidi Youssef, beach, 11 dd (SDP), 19 dd (GBP); Sfax, fishing nets residuals, 1 lv (MOP); Borj Djillidj, Djerba, 2 lv (RHP); Bou Grara, littoral, 3 lv (RHP); NW of Bou Grara Sea, $-10 / 15 \mathrm{~m}, 2$ paratypes of O. aciculata exilis Houart, 2001 (RHP).

Ocinebrina reinai Bonomolo and Crocetta n. sp.

Italy: Livorno, $43^{\circ} 33^{\prime} \mathrm{N}, 010^{\circ} 13^{\prime} \mathrm{E}$ trawler residuals, $1 \mathrm{dd}$ (RHP), $1 \mathrm{dd}$ (WHP); Capraia Island, $43^{\circ} 01^{\prime} \mathrm{N}, 009^{\circ} 51^{\prime} \mathrm{E}, 4 \mathrm{lv}, 1 \mathrm{dd}$ (GBP), 1 dd (FCP), 1 dd (MRP), 1 dd (FDP); Montalto di Castro, $42^{\circ} 18^{\prime} \mathrm{N}, 011^{\circ} 33^{\prime} \mathrm{E}$, gill nets, $1 \mathrm{lv}, 1$ dd (GBP); off Ladispoli, gill nets, 3 lv, 1 dd (GBP); "Secche di Tor Paterno" Marine Protected Area: Stn $\mathrm{S} 1\left(41^{\circ} 36^{\prime} 21 » \mathrm{~N}, 012^{\circ} 20^{\prime} 28 » \mathrm{E}\right.$, horizontal coralligenous substratum with Eunicella spp., -25 m), Stn S22 (41 $36^{\prime} 13$ ”N, $012^{\circ} 20^{\prime} 30^{\prime \prime} \mathrm{E}$, horizontal coralligenous substratum with rare Eunicella spp., -20 m), Stn R2 (4136'13”N, 012²0’30”E, Posidonia oceanica patches on hard substratum, foliar layer, -24 m); Stns SP2-SP3 $\left(41^{\circ} 36^{\prime} 21^{\prime \prime} \mathrm{N}, 012^{\circ} 20^{\prime} 28^{\prime \prime} \mathrm{E}, P\right.$. oceanica patches on hard substratum, rhizome layer, -26 m), Stns SP4-SP5 (41 ${ }^{\circ} 36^{\prime} 13^{\prime \prime N}$, $12^{\circ} 20^{\prime} 30^{\prime \prime} \mathrm{E}, P$. oceanica field on soft substratum, rhizome layer, $-26 \mathrm{~m}) 8 \mathrm{lv}$ used for genetics (SP3-04, R2-02, SP2-04, SP4-17, SP418, SP3-02, S1/BAU1038, S22/BAU1039); Pozzuoli, 4048'N, $014^{\circ} 06^{\prime} \mathrm{E}$, gill nets, $2 \mathrm{lv}$ (PSP); Procida Island, $40^{\circ} 46^{\prime} \mathrm{N}, 014^{\circ} 01^{\prime} \mathrm{E}$, snorkelling, in $P$. oceanica patches, $1 \mathrm{lv}$, (GFP); - $38 \mathrm{~m}$, dredge, $1 \mathrm{dd}$ (GFP); Marina di Puolo, 40³7’ N, 014'18'E, gill nets, 2 lv (SDP); Mergellina, $40^{\circ} 49^{\prime} \mathrm{N}, 14^{\circ} 13^{\prime} \mathrm{E}$ beached, 4 dd (GFP); Capri Island, $40^{\circ} 34^{\prime} \mathrm{N}, 014^{\circ} 12^{\prime} \mathrm{E}, 1 \mathrm{lv}, 4 \mathrm{dd}(\mathrm{GBP}), 2 \mathrm{lv},-10 \mathrm{~m}$, shell grit (GFP); Tavolara Island (Sardinia), 4054’ N, $009^{\circ} 42^{\prime} \mathrm{E}, 1 \mathrm{lv}, 1 \mathrm{dd}$ (GBP). 